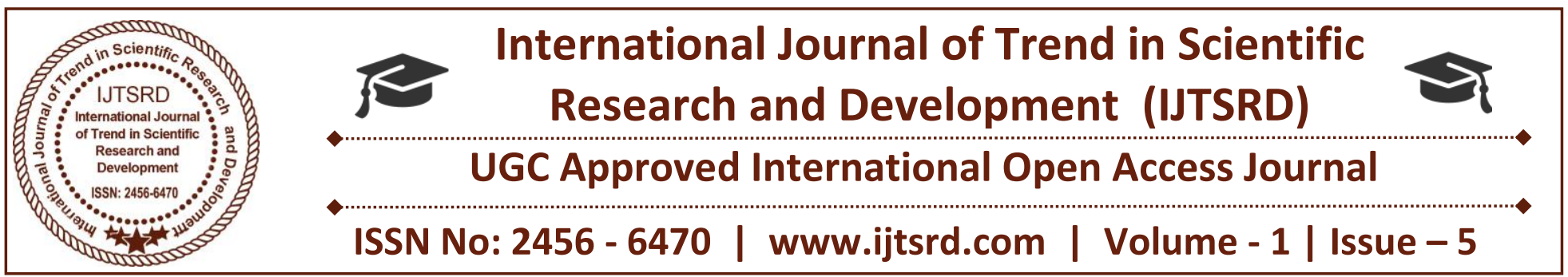

\title{
The Political Economy of Criminal Justic System Reform in Nigeria (2000-2009)
}

\author{
Dr. Gbenemene Kpae \\ University of Port Harcourt, Rivers State, Nigeria
}

\author{
Dr. Comfort Nwideeduh \\ University of Port Harcourt, Rivers State, Nigeria
}

\begin{abstract}
The smooth running of the criminal justice system is very essential in the socio-economic development of every nation. It helps in curbing criminality and the maintenance of law and order in society. However, where the criminal justice system is dysfunctional, anarchy and lawlessness rather than rule of law becomes the order of the day, and that seems to be the situation in Nigeria today. The prevalence of violent crimes such as street crimes, cultism, militancy, and terrorism has made lives and property insecure, and the criminal justice system seems overwhelmed to contain the situation. The Nigerian criminal justice system has been plagued by several problems particularly issues relating to prison overcrowding, unlawful detention, corruption, extra-judicial killing, and human rights abuses. These violations have diminished public trust in the criminal justice system, especially the police force, and have affected the institution in the discharge of its responsibility of crime control. In an effort to make the criminal justice system more effective in tackling Nigerian security challenges, governments have set up various reforms committees. Unfortunately, many of the recommendations and white papers from these panels have remained without implementations. This paper focuses on the criminal justice reforms that were introduced since the return of democratic government in 1999. We recommend a implementation of reports of reformation of the criminal justice system as a way of decongesting the prison, making the police more efficient, and to eliminate delay in administration of justice
\end{abstract}

Keywords: Political economy, criminal justice system, reform, Nigeria

\section{INTRODUCTION}

The Nigerian criminal justice system has been facing difficult challenges that have been affecting effective discharge of its functions. Some of the problems include increase in crime rate, prison overcrowding and delay in the dispensation of justice. Nigerian prison system contains more people than its carrying capacity. For example, the prison has capacity for slightly 47,000 inmates while it actually contains above 50,000 inmates (Guardian, 20 ${ }^{\text {th }}$ May, 2015). This situation causes prison congestions, and leading to infrastructural decay in most prisons that causes poor sanitary condition, and resulting to ill-health of inmates. Another problem with the criminal justice system has been that of justice delay. There is serious delay in the dispensation of justice in Nigeria resulting to politicians and many influential Nigerians taking advantage of the loophole to evade conviction.

The problem of increasing crime rates, prison and court congestion and cases of corruption against judges and police officers has increased the demand by the public and other non-governmental organisations for reformation of the Nigerian criminal justice system. However, most government reforms have been on the police, we is the focus of this paper. The police are still operating the antiquated method of combating crime and have been unable to keep pace with the current wave of criminality that Nigeria is 
currently experiencing. The prevalence of violent crimes and street crimes has rendered lives and property very unsafe in most part of Nigeria. Many communities have formed vigilante groups to guide community neigbourhoods against predatory criminals, while some individuals and businesses have installed Close Circuit Cameras (CCTV) around their houses and business premises in order to curb the menace of street criminals. However, despite these precautionary measures taken by the public, criminality continues to be on the increase. The Nigeria police are poorly trained and ill-equipped to deal with the rising level of violent crimes that has taken over most cities in Nigeria. In order to tackle this menace, the government has set up panels to reform the police force. However, many of the reports and recommendations seem to have remained on the tables of the presidents without further actions. This paper dwells more on the police force because they are the most vital organ among the criminal justice agencies in the fight crime and keeping our society safe. Other criminal justice agencies such as the courts and prisons have less direct contact with the public; they only receive people (criminal suspects) after they have been processed by the police. The police role in criminal justice administration in Nigeria is also very important because they are the first point of call whenever a crime incident occurs, and they determine whether a criminal suspect would be admitted into the criminal justice system. We, therefore, centre our analysis and discussion on police reforms under President Obasanjo administration, that is, 2000 to 2009 . This period under review is very critical in our analysis because, it marks the beginning of democratic dispensation in Nigeria after several decades of dictatorial military rule.

In analyzing police reforms since the inception of democratic governance in Nigeria, some critical questions have to be addressed. What are the major reforms or improvements in the Nigeria Police since the civilian democratic regime? To what extent has the Nigeria police transformed from colonial, military and postcolonial/post-military policing to a civil and democratic police force? These questions can only be addressed if we examine the history of policing in Nigeria, the economic situation during the period and some of the reforms introduced after Obasanjo became president in 1999.

\section{DEFINITION OF CONCEPTS}

\section{Criminal Justice System:}

It refers to the institution through which criminal suspects are processed. It also consists of the entire system that handles all cases of criminal processing, that is, from arrest, prosecution to incarceration at the penitentiary. The system has three main components namely: police, judiciary, and prisons or correction departments.

\section{Criminal Justice System Reform:}

It refers to a type of reform that is intended to cure some of the defects in the criminal justice system. The aim of such reforms will be to make the police more efficient, reduce prison population, and eliminate the delay in the dispensation of justice.

\section{The 2000 Obasanjo Government Institutional Reform}

Before the 2000 Obasanjo government's instituted reform, the Nigeria police seem to have defied any attempt by anybody to reform it. This can be blamed on the antecedents of their origin and historical realities of the Nigeria State. Generally, we may correctly describe the era of democratic government as the reform era, judging from the historical antecedents (Nwideeduh, and Gbenemene, 2016).

After receiving the mandate and mantle of Leadership in 1999, in 2000, the Obasanjo civilian government set out to reform the Nigeria police. The reform was necessary to make the police a civil and democratic police in line with Nigeria's transition from military dictatorship to constitutional democracy. Prior to the reform, there was obvious decay in the general operation of the force. To effect the reform, the Ministry of Police Affairs and the Office of InspectorGeneral of Police were mandated to produce a blueprint for the overhaul of the force. They, therefore, submitted a five-year development plan for the reform of the police.

In order to do a thorough job, they consulted police agencies of the advanced capitalist economies and all the collaborative approach came under the aegis of the Network on Police Reform in Nigeria (NOPRIN). NOPRIN was formed in July 2000 when the USAID/OTI (United States Agency for International Development/Office of the Transition Initiatives - 
agencies of the United States of America Government) and DFID (Department for international Development) - an agency of the United Kingdom government) organized a workshop for many NGOs involved in police-related activities in Nigeria.

The NGOs present at the workshop agreed to form a network in order to shave information and resources to assist the Nigeria police in their democratic reforms, in view of the above, series pf consultative meetings were held including those with the international committee of the Red Cross, USA and UK retired policing experts. Also, involved were representatives of the Ministry of Police Affairs and the Office of Inspector General of Police. The outcome of the whole initiatives is what we are referring to as NOPRIN.

The cardinal objective was to structurally reform the police. Secondly, the operational pattern was to be reformed from the present reactive policing to proactive operational system and from crime fighting to crime prevention operational model. This is why the experiment on community policing started in designated areas like Enugu where community liaison units were established to bring the police back to the community. Infrastructurally, the police got more operational vehicles, helicopter, better guns and improved salary. The target was to meet the international standard of policing. There has been massive recruitment of new personnel in order to meet the United Nations standard of 400 people to one police.

\section{The Political Economy of Nigeria during the Period under Review}

The transition from military dictatorship to a civil government was expected to bring economic boom to Nigerians, who have suffered economic crisis occasioned by many years of military mismanagement. The Olusegun Obasanjo civil government began well by presenting a very timely appropriation bill that was quickly approved by the National Assembly. However, certain deficiencies were very noticeable in the appropriation bill. For instance, education got only $7 \%$ of the total budget allocation, contrary to UNESCO recommended standard of $26 \%$. In the same way the 2000 appropriation bill allocated less than $20 \%$ on Health.

Some of the key sectors that seem to hold the national economy, like the energy sector, was given allocation that seem to suggest that the government was determined to resuscitate the sector. However, after sonic months, the petroleum refineries were still not producing at full capacity. Fuel importation increased instead of decreasing. The government announced its determination to deregulate the mainstream oil sector. Nigeria being a mono-centric economy relied only on petroleum export without any attempt to develop other sectors of the economy. The result was a general increase in the price of goods and services, unemployment and total economic failure.

As a result of the economic downturn more than 130 companies folded up (Omolade, Adunbi, 2000: 101). In view of the above, the Manufacturers Association of Nigeria passed a verdict of lack of performance on the government. The body based its assessment on the total collapse of social and economic infrastructure caused by erratic power supply and the high cost of doing business including weak consumer demand arising from reduced purchasing power.

Despite the clear economic problems caused by improper budget and fiscal management the government continued to deceive the citizens that there is economic growth. According to the then Minister of Transport, Chief Ojo Maduekwe (in Thisday Newspaper of November 2, 2000):

All the known economic indicators showed that the economy was no longer in bad shape; the rate of inflation in the country has moved down to single digit while there is more money in the pockets of Nigerians.

The open denial of economic crisis despite long fuel queues and many Nigerians torched to death while struggle to get fuel in filling stations is to say the least a hard-line posture of a government that is insensitive to the sufferings of the people that gave it the mandate to manage their socioeconomic affairs.

\section{IMF LQAN DEBATE}

Among the political economy-related issues during the period under review is the debate on whether Nigeria should accept IMF loan or not. It should be recalled that the Banbagida administration presented the same debate in 1989 and eventually took the loan. It was the loan that plunged Nigeria into the economic crisis that we are battling till this day. The Federal Government of Olusegun Obasanjo again presented a 
bill to obtain another IMP loan of one billion dollars. But the hallowed lower chamber (the House of Representatives) kicked against it. The House argued that the country indebted to the tune of $\$ 30$ billion and appealing to the Britonwood institutions for debt relief and forgiveness should not accept further loan.

Obviously the high rate of corruption in all the institutions of the Nigeria state cannot guarantee a good fiscal management. All the previous loans were embezzled through various graft and looting techniques best known to the ruling class in Nigeria. The Bill was therefore thrown out by the National Assembly.

\section{New Economic Blueprint}

Despite all the economic problems that confronted the Obasanjo government, it still went ahead to release a blueprint to tackle the problem of unemployment, raise the standards of living of Nigerians and actively engage in the global market competition. The government also stated that the blueprint would enable it to rehabilitate collapsed infrastructure, ensure adequate supply of fuel, reduce the debt burden, interests and inflation rates, encourage small and medium scale industries and give adequate attention to agriculture. The government hired the services of Citizens' International-an international non-governmental organization to draw the blueprint. A fund of $\mathrm{N} 7$ billion was made available and was tagged New Nigeria Fund (NNF).

However, the blueprint and the fund were faulted by the Manufacturers Association of Nigeria (MAN) and the Chartered Institute of Bankers of Nigeria (CIBN). The professional associations and trade unions hinged their criticism on their assessment of the blueprint as lacking clear objectives and targets within a definable timeframe. MAN said they expected quantitative targets on gross domestic products, employment and capacity utilization on annual basis while the CIBN criticized the lack of schedule necessary for measuring achievement and implementation procedure.

\section{Deepening Energy Crisis}

The appointment of Bola lge as the Minister of Power and Steel was greeted with mixed feelings because he was a lawyer. However, his integrity was not in question. Ige promised to reduce power outage by $60 \%$ in the first six months of the government in office and to eradicate outages by the first quarter of the year 2000. This target was not achieved at all and the Minister's attempt to uncover the cabal of corrupt NEPA officials may have caused his gruesome murder. Despite the removal of the Suleiman Belloled management team of NEPA and the replacement of same with a technical board led by former Senator Liyel lmoke, the problem of power generation still haunts Nigerians till today.

Energy experts have estimated an average national power demand of 2,470 megawtts while NEPA was only able to generate 1,600 megawatts. As at today, the power crisis seems to be worsening instead of improving.

\section{Poverty Alleviation Programme}

In the attempt to reduce poverty, the administration launched the Poverty Alleviation Programme (PAP). The cardinal objectives of the programme include:

i) To enhance capacity utilization in agriculture, manufacturing and mining industries;

ii) To provide appropriate protection of domestic industries against unfair competition from imports and dumping;

iii) to encourage diversification of foreign exchange earning through increased export activities;

iv) to provide appropriate incentives for investment in manufacturing, agriculture and mining in order to make the economy private sectordriven;

v) to create about 200,000 jobs across the country.

Today, it has become obvious that PAP did not achieve the above objectives; instead it has only assisted in micro-investment and craft and minor occupations that cannot make the economy private sector-driven. Experience has shown that our export has continued to reduce, many industries like textile have totally collapsed and more and more graduates are produced annually without assurance of any means of livelihood. The agricultural sector has continued to lag behind like previous programmes such as OFN, Green Revolution, DFFRI, NDE, FSP, FEAP and Better Life; the PAP programme did not achieve impressive result.

\section{Impact of the Political Economy on Citizens}

The general impact of the poor economic and administrative policies of the government was a total collapse of the economy. All market indicators such as price of household items, food, fuel, energy, health, education and welfare institutions all gave a poor 
mark to the fiscal policies of the administration. The only beneficiaries were PDP members in power and party loyalists who got contracts.

The reaction of the people came in form of strikes, demand for increase in wages, ethnic militia, and increase in the demand for resource control by oilbearing communities. In the Niger Delta, the militants began to operate openly, kidnapping expatriate oil workers and destroying oil installations in many areas. The Non-Academic Staff Union of Universities (NASU) embarked on a strike for improved welfare; the Academic Staff Union of Universities (ASUU), Nigeria Labour Congress (NLC), National Association of Resident Doctors (NARD) all embarked on strike to protest the depleting income occasioned by inflation and the economic downturn. Ethnic vigilante groups such as Bakassi in the East, Odua People's Congress (OPC), Movement for the Actualisation of the Sovereign State of Biafra (MASSOB), Northern Peoples Congress (NPC) and other quasi-ethnic and mass uprising groups emerged to indicate the failure of the government to maintain law and order.

\section{The Police Role during the Period}

The Truth and Justice (Human Rights) Commission set up by the Obasanjo government to review human rights abuses in Nigeria headed by Retired Justice Chukwudifu Oputa exposed the role of the police and the army during the period of military dictatorshp. The report, partly published in The Guardian of $3^{\text {rd }}$ January 2005 has this to say:

From the evidence, which the Commission received, it is clear that the quest for political power and personal enrichment was largely the driving force... The military tended to treat the state (Nigeria) as a conquered territory and proceeded to treat the proceeds of the state as spoils of war to be shared among the members of the military, the conquering force of occupation.

It is doubtful if there is any difference between political office holders of the period under review and the military occupation force that Justice Oputa described. The police was opening assisting the political office holders in their anti-people oriented policies.

According to Okey Nwanguma and Ijeoma Nwachukwu of Civil Liberties Organisation,
The police proved unable to fulfill their primary functions. Indeed, their failure to meet the security and safety needs of the citizens continued to promote public loss of confidence in the police and resort by disgruntled citizens to desperate self-help options. The high incidence of mob justice attested to this. (Annual Report 2000 on the state of human rights in Nigeria. Civil Liberties Organisation).

The culture of impunity, corruption, brutality, collusion, torture in police cells, extra-judicial killings, extortion, arbitrary arrest and indefinite detention in police custodies continued within the period under review. The upsurge of ethnic, religious and sectarian violence across the country suggests a failure on the part of the government. The activities of the vigilante groups and ethnic militias increased and took a dangerous turn, with incessant clashes with law enforcement officials. The vigilante groups used brutal, lawless and barbaric methods but enjoyed the patronage of some serving governors and government officials. The Bakassi in Aba for instance, subjected their victims to ordeal trial and public butchery. The OPC in Lagos burnt many people alive. Sometimes these lawless groups are accompanied by the police and their activities are said to be known by the Police.

\section{Police Reforms Initiative}

The Nigeria police force was established in 1930 by the amalgamation of the two separate protectorate forces of Northern and Southern Nigeria. Until 1960, the force co-existed with numerous local police forces in the North and Western regions. In the first republic, there were widespread complaints against local police forces. The complaints against them included local and sub-standard recruitment of personnel, poor training, use of the police to oppress political opponents and rigging of elections. There was widespread allegation that Northern and Western local police forces were used for political thuggery during 1 964 and 1965 elections (Tamuno, T N, 1970; Ahire, P T, 1993; and Rotimi, 1993).

It was the regime of Major-General JTU Ironsi that set up a panel to investigate the allegations against regional police. This was some of the reasons that the regime was seen as a unitary system of government. The head of state was killed before the panel submitted its report. The General Gowon-led military government received the report and dissolved regional police forces. 
The dissolution of regional police forces marked the origin of a centralized structure of the Nigeria police till date. Both the 1979 and 1999 Constitutions provided that there shall be only one police force in Nigeria.

\section{The Police Service Commission}

In many countries, the police have often been left alone to organize, control and discipline itself with limited oversight exercised by the courts. However, the vulnerability of the police to abuse of discretional powers and partisan control by political authorities has called to question the essence of police discretionary powers. Moreover, within the internal administration of the police, officers have questioned the fairness of some of their internal disciplinary measures leading to court cases challenging sanctions, demotions and dismissals.

To oversee the activities, especially the abuse of power and authority by the police, the 1999 Constitution of Nigeria established the Police Service Commission. Prior to the establishment of the PSC, citizens aggrieved by police misconduct go back to the police to report or complain. In the same way, police officers who were unjustly sanctioned, demoted, sacked or dismissed from service had no place to lay their complaint if they do not have all it takes to go to court. The inauguration of the Police Service Commission on 28 November 2001 by the Obasanjo administration created a good institutional mechanism for accountability and oversight of the Nigeria Police Force (NPF). Now, the police is accountable to the public and its personnel have got a dispute and grievance settlement channel.

\section{The Economic Financial crimes Commission (EFCC) 2004}

The establishment of the Economic and Financial Crimes Commission (EFCC) in 2004 by the Obasanjo regime was a landmark in anti-corruption war in the country. Prior to the establishment of the EFCC, there was visible lack of transparency and accountability in our public service. Corruption in form of graft, embezzlement and contract racketeering was very common practice in our service. The Commission was empowered to prevent, investigate, prosecute and penalize economic and financial crimes. It is also charged with the responsibility of enforcing the Provisions of other laws and regulations relating to economic and financial crimes, including: i) The Money Laundering Act, 1995.

ii) The Money Laundering (Prohibition) Act, 2004. iii) The Advanced Fee Fraud and other Fraud-related Offences Act, 1995.

iv) The Failed Banks (Recovery of Debts) and Financial Malpractices in Banks Act, 1994.

v) The Banks and Other Financial Institutions Act 1991, and

vi) Miscellaneous Offences Act.

vii) Terrorism Surveillance.

\section{The Independent Corrupt Practices and other}

\section{Related Offence Commission (ICPC)}

$\mathrm{n}$ reaction to the high rate of corruption in Nigeria, the Olusegun

Obasanjo government also promulgated the Corrupt Practices and other related Offence Act 2000. This was the first Bill that the president presented to the National Assembly at the inception of his government. The mandate of the Commission is to prohibit and prescribe punishment for corrupt practices and other related offences.

The ICPC by Section 6 of the Act, is given three main functions in the fight against corruption:

i) To receive and investigate reports of corruption and in appropriate cases prosecute the offenders.

ii) To examine, review and enforce the correction of corruption prone systems and procedures of public bodies, with a view to eliminating corruption in public life.

iii) Educating and enlightening the public on and against corruption and related offences with a view to enlisting and fostering public support for the fight against corruption.

A close look at the reforms within the period under review indicates that the police has been operationally reformed to a relative extent. The Yar'Adua government avowed resolve to uphold the rule of law is another positive development in the institution of law enforcement and justice process in Nigeria. However, the culture of corruption among the officers is still common. The $\mathrm{N} 20-\mathrm{N} 100$ collections from commercial motorists are still rampant today. To what extent can a corrupt police force fight crime and corruption? In a capitalist society where every available service is reduced to monetary value, can the police live above the culture of their society's sociopolitical economy? 


\section{CONCLUSION}

In spite of all structural and operational reforms in the Nigeria Police Force (NPF), the vestiges of incivility, corruption and human rights abuses still pervade the force. There is the need for moral reforms since all other forms of reform seem not to have changed the institution of corruption in the force. The removal of the former Inspector General of Police, Mr. Tafa Balogun, on corruption charges and the continuation of corruption in the Ehindero regime and that of Ogbonna Onovo regime is an indication that neither welfare improvement nor infrastructural provision can stamp out corruption in the force. The only explanation can be found in the examination of the political economy of the Nigeria state. The police are not men from the moon; they are part and parcel of the emasculated state and the culture of materialism and corruption cannot be alien to men and women of the force. This reputation of corruption against the police has affected criminal justice administration in Nigeria and the fight against complex crime and transnational offences. We recommend a value reorientation among the Nigerian populace, and proper coordination among the various arms of the criminal justice system in order to make criminal justice administration more efficient. More importantly, the government should ensure that its implements recommendations and white papers on criminal justice reforms in Nigeria as a way of decongesting our prisons, and ensuring that police needs are well catered for.

\section{REFERENCES}

1) Omolade Addeinbi (2000). Socioeconomic conditions: Animal report 2000 on the state of Human Rights in Nigeria by CLO.

2) Thisday Newspaper, November 2, 2000.

3) The Guardian Newspaper, $3^{\text {rd }}$ January 2005.

4) The Guardian Newspaper, 20 ${ }^{\text {th }}$ May, 2014. "Time to mend Nigeria's criminal justice system".

5) Nwanguma, O., \& Nwachuckwu, 1. (2000). Policing and individual liberty. Annual Report of CLO 2000.

6) Nwideeduh, C. and Gbenemene, K. (2016) Security Challenges to the police in the $21^{\text {st }}$ century: Imperative for reform of the police institution.

7) Tamuno, T. N. (1970). The police iii modern Nigeria. Ibadan: University of Ibadan Press.
8) Ahire, P. T. (1993). Native authority in Northern Nigeria: End of an Era, in T. N. Tamuno, 1. L. Bashir, C.C. Alenika and A. O. Akano (eds.), Poilcing Nigeria: Past, present and future. Lagos: Nigeria Police Force and Malthouse Press Ltd.

9) Rotimi, K. (1993). Local Police in Western Nigeria: End of an Era, In I. N. Tamuno, I. L. Bashir, E. C. Alenika and A. O. Akano: Policing Nigeria: Past, present and future. Lagos: Nigeria Police Force and Maithouse Press Ltd. 